\title{
A precise age for the Utopia Granite, southwestern New Brunswick, Canada
}

\author{
S.M. BARR ${ }^{1 *}$, J.K. Mortensen ${ }^{2}$, And M.L. BevieR ${ }^{2}$ \\ 1. Department of Earth and Environmental Science, Acadia University, Wolfville, Nova Scotia B4P 2R6, Canada \\ 2. Department of Earth and Ocean Sciences, University of British Columbia, Vancouver, British Columbia V6T 1Z4, Canada \\ *Corresponding author <sandra.barr@acadiau.ca $>$
}

Date received: 01 January 2010 Date accepted: 23 February 2010

\begin{abstract}
The Utopia Granite is part of the Saint George Plutonic Suite, a gabbroic to granitic assemblage of plutons of Late Silurian - Late Devonian age in southwestern New Brunswick. New U-Pb (ID-TIMS) analyses of five fractions of strongly air-abraded zircon grains define a discordant array which suggests that all five fractions have suffered at least some minor degree of post-crystallization Pb-loss and yielded an imprecise upper intercept age of $426.3 \pm 5.9 \mathrm{Ma}$. Fifteen zircon grains analyzed by LA-ICP-MS yielded overlapping concordant analyses, from which a weighted average of the ${ }^{206} \mathrm{~Pb} /{ }^{238} \mathrm{U}$ ages, excluding one younger age, is $428.3 \pm 1.0 \mathrm{Ma}(\mathrm{MSWD}=0.66$, probability of fit $=0.81)$, which we interpret as the best estimate for the crystallization age of the Utopia Granite. This age suggests that the Utopia Granite may be the oldest component of the Saint George batholith, and 5-8 million years older than plutons of the contiguous coastal Maine magmatic province to the southwest.

\section{RÉSUMÉ}

Le granite Utopia fait partie de la suite plutonique de Saint-George, un assemblage gabbroïque à granitique de plutons du Silurien tardif et de la fin du Dévonien, dans le sud-ouest du Nouveau-Brunswick. De nouvelles analyses U-Pb (ID-TIMS) de cinq fractions de grains de zircon fortement altérés par l'air indiqueraient un assemblage discordant qui porte à croire que les cinq fractions ont subi au moins en partie une perte de plomb après la cristallisation. Les analyses ont permis d'établir de manière imprécise un âge géologique de 426,3 $\pm 5.9 \mathrm{Ma}$. Quinze grains de zircon analysés à l'aide des méthode LA-ICP-MS ont produit des résultats concordants qui se recoupaient, dont on a tiré une moyenne pondérée des âges ${ }^{206} \mathrm{~Pb} /{ }^{238} \mathrm{U}$ de $428,3 \pm 1,0 \mathrm{Ma}$, exception faite d'un âge plus jeune (déviation pondérée de la régression par moindres carrés $=0,66$, probabilité de congruence $=0,81$ ). Nous croyons qu'il s'agit là de la meilleure estimation qui soit de la période de cristallisation du granite Utopia. Ces analyses de datation suggèrent que le granite Utopia pourrait être la partie la plus ancienne du batholithe Saint-George, et de 5 à 8 millions d'années plus ancienne que les plutons de la province magmatique de la zone côtière contigüe du Maine, au sud-ouest.
\end{abstract}

[Traduit par la redaction]

\section{INTRODUCTION}

The Utopia Granite is part of the Saint George Plutonic Suite, also known informally as the Saint George batholith, in southern New Brunswick (Fig. 1). According to the current New Brunswick lexicon of bedrock geology (New Brunswick Department of Natural Resources 2010), the Saint George Plutonic Suite is a contiguous cluster of mainly high-level intrusive rocks comprising (in inferred chronological order from oldest to youngest) the Bocabec Gabbro, Utopia Granite, Welsford, Jake Lee Mountain, and Parks Brook alkali granites, Magaguadavic Granite, John Lee Brook Granite, and Mount Douglas Granite. The age of the Saint George Plutonic Suite is broadly assigned to the Late Silurian to Late Devonian (New Brunswick Department of Natural Resources 2010), but the absolute ages of some of the constituent plutons are not well constrained. The purpose of this paper is to report new $\mathrm{U}-\mathrm{Pb}$ zircon ages for the Utopia Granite based on both TIMS and laser ablation (LA) ICP-MS dating, the latter of which provides a precise age for the granite.

\section{GEOLOGICAL SETTING AND FIELD RELATIONS}

The Saint George Plutonic Suite intruded mainly Silurian sedimentary and volcanic rocks of the Mascarene terrane, but 
also intruded across terrane boundaries into the New River terrane in the south and the St. Croix terrane and Fredericton belt in the north (Fig. 1). All of these areas are interpreted to be part of Ganderia (Hibbard et al. 2006; Fyffe et al. 2009).

The Utopia Granite underlies an area of about $90 \mathrm{~km}^{2}$ in the southwestern part of the Saint George Plutonic Suite (Fig. 1). Ruitenberg and Fyffe (1982) introduced the name Utopia Granite during a regional metallogenic study of granitic rocks in the province. Along its southern margin, the Utopia Granite intruded bimodal volcanic and fossiliferous sedimentary rocks of the Eastport Formation of the Mascarene Group. Biotite hornfels is developed locally in the contact zone near Lake Utopia, and equigranular to porphyritic microgranite is common along the southern contact of the granite, consistent with the intrusive relationship (McLeod 1990). McLeod (1990) described the northwestern margin of the granite as intrusive into the Bocabec Gabbro, but based on the presence of mixing/ mingling textures the two units were considered to have been more or less coeval. Fyffe (1971) also described co-mingling of granitic and gabbroic units in the Bocabec Gabbro, but did not attribute the granitic component to the Utopia Granite. McLeod (1990) suggested that rounded, partially assimilated

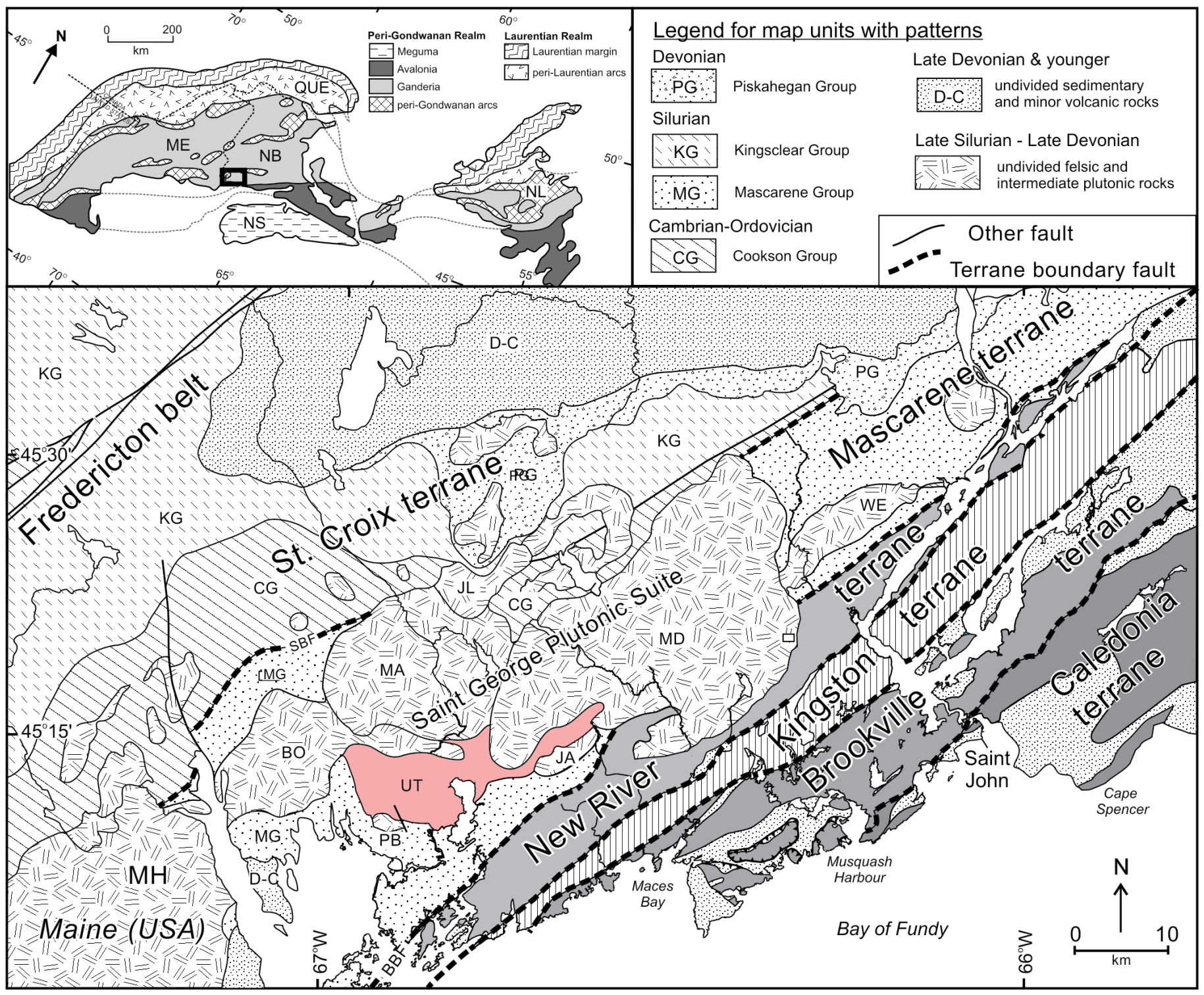

Fig. 1. Geological map of the Saint George Plutonic Suite and surrounding area in southern New Brunswick and adjacent Maine after King and Barr (2004) and McLaughlin et al. (2003). Inset map shows the location of the area in the context of Appalachian terranes after Hibbard et al. (2006). Abbreviations for plutonic units: BO, Bocobec Gabbro; JL, John Lee Brook Granite; JA, Jake Lee Mountain Granite; MA, Magaguadavic Granite; MD, Mount Douglas Granite; MH, Moosehorn Plutonic Suite; PB, Parks Brook Granite; UT, Utopia Granite; WE, Welsford Granite. Other abbreviations: BBF, Back Bay fault; SBF, Sawyer Brook fault. 
mafic xenoliths that occur sporadically throughout the Utopia Granite could be related to the Bocabec Gabbro, although that relationship is not definitive.

Near its southwestern and southeastern margins, respectively, the Utopia Granite has been interpreted to have intruded alkali-feldspar granite of the Parks Brook and Jake Lee Mountain plutons (McLeod 1990; Currie 2003). These alkalifeldspar granite plutons are considered to be correlative with the Welsford Granite (e.g., Currie 2003), which has yielded a U-Pb zircon age of $422 \pm 1 \mathrm{Ma}$ (Bevier 1990), and collectively these plutons have been termed the Welsford Intrusive Suite (McLeod 1990). If this correlation is correct, then that age is a maximum for the Utopia Granite. Contacts of the Utopia Granite with the ca. 396 Ma Magaguadavic and ca. $366 \mathrm{Ma}$ Mount Douglas granites to the north have not been observed; however, outcrop patterns are consistent with the geochronological data (Bevier 1990) which indicate that these plutons are younger than the Utopia Granite. McLaughlin (2003) suggested that the Utopia Granite might be a more evolved component of the magma that formed the Baring Granite in Maine, for which McLaughlin et al. (2003) reported an age of $421.1 \pm 0.8 \mathrm{Ma}$.

\section{PREVIOUS DATING OF THE UTOPIA GRANITE}

Fyffe et al. (1981) reported a $\mathrm{Rb}$-Sr whole rock age of $406 \pm 7$ Ma for the Utopia Granite, and Bevier (1990) reported a preliminary U-Pb zircon age of $430 \pm 3$ Ma. McLeod (1990) pointed out that the latter age contradicts fossil evidence, which indicates an Early Devonian age for the Eastport Formation in the contact aureole of the granite. Consequently, he proposed that the ${ }^{40} \mathrm{Ar} /{ }^{39} \mathrm{Ar}$ on biotite total gas age of $418 \pm 5 \mathrm{Ma}$ is probably a more accurate indication of the age of the Utopia Granite. However, a discrepancy relating to the absolute age of the fossils was revealed later when Silurian U-Pb ages were obtained from volcanic rocks elsewhere in the Eastport Formation (Van Wagoner and Dadd 2003). Early Silurian U-Pb ages have also been reported for rhyolite in the Letete and Waweig formations of the Mascarene Group, further suggesting that the fossil evidence for the age of the group may not be reliable (Miller and Fyffe 2002).

Re-examination of the U-Pb data of Bevier (1990) resulted in an amended age for the Utopia Granite of $423 \pm 3 \mathrm{Ma}$ (M.L. Bevier, cited in McLaughlin 2003), similar to the U-Pb age of the Baring Granite, which McLaughlin (2003) and McLaughlin et al. (2003) considered to be co-magmatic with the Utopia Granite based on petrological similarities.

\section{NEW U-PB DATA}

The uncertainties related to the age of the Utopia Granite and its host rocks motivated the authors to resample the granite for $\mathrm{U}-\mathrm{Pb}$ dating at the Pacific Centre for Isotopic and Geochemical Research(PCIGR). The new sample was collected from the type locality of the Utopia Granite, from the same location where McLeod (1990) collected the argon dating sample, along Route 785 along the east shore of Lake Utopia to the south of Mill Lake on NTS $21 \mathrm{G} / 02 \mathrm{~W}$. The sample is red, medium-grained, equigranular syenogranite transitional to monzogranite. Zircon grains were separated using conventional crushing, grinding and wet shaking table methods, followed by heavy liquid and magnetic separation. The sample yielded abundant zircons, comprising clear, pale brown, stubby to elongate, square prisms with simple terminations. Rare clear bubble-shaped inclusions were present in some grains; however, no internal zoning or inherited cores were observed under a binocular microscope or in transmitted light.

The methodology used for TIMS analyses at the PCIGR was as described by Mortensen et al. (1995). The outer portions of the grains were removed using air-abrasion methods prior to dissolution in order to minimize the effects of post-crystallization $\mathrm{Pb}$-loss. Individual fractions for analysis ranged from 1 to 11 grains. Zircons were also dated using laser ablation (LA) ICP-MS methods, using methods as described by Tafti et al. (2008). Instrumentation employed for LA-ICP-MS dating of zircons at the PCIGR comprises a New Wave UP-213 laser ablation system and a ThermoFinnigan Element 2 single collector, double-focusing, magnetic sector ICP-MS. Zircons were handpicked from the heavy mineral concentrate and mounted in an epoxy puck along with several grains of the Plešovice zircon standard (Sláma et al. 2007), together with a separate in-house, $197 \mathrm{Ma}$ standard zircon, and brought to a very high polish. High quality portions of each grain free of alteration, inclusions, or possible inherited cores were selected for analysis. The surface of the mount was washed for 10 minutes with dilute nitric acid and rinsed in ultraclean water prior to analysis. Line scans were employed in order to minimize elemental fractionation during the analyses. Backgrounds were measured with the laser shutter closed for ten seconds, followed by data collection with the laser firing for approximately 29 seconds. The time-integrated signals were analysed using GLITTER software (Van Achterbergh et al. 2001; Griffin et al. 2008), which automatically subtracts background measurements, propagates all analytical errors, and calculates isotopic ratios and ages. Corrections for mass and elemental fractionation were made by bracketing analyses of unknown grains with replicate analyses of the Plešovice zircon standard. A typical analytical session at the PCIGR consists of four analyses of the standard zircon, followed by four analyses of unknown zircons, two standard analyses, four unknown analyses, etc., and finally four standard analyses. The $197 \mathrm{Ma}$ in-house zircon standard was analysed as an unknown in order to monitor the reproducibility of the age determinations on a run-to-run basis. Final interpretation and plotting of the analytical results employed the ISOPLOT software (Ludwig 2003). The final interpreted age for the sample is based on a weighted average of the individual calculated ${ }^{206} \mathrm{~Pb} /{ }^{238} \mathrm{U}$ ages.

Five fractions of strongly air-abraded zircon were analyzed using ID-TIMS methods (Table 1). Four of the analyses are statistically concordant, but show some scatter along concordia 
ATLANTIC GEOLOGY $\cdot$ VOLUME $46 \cdot 2010$
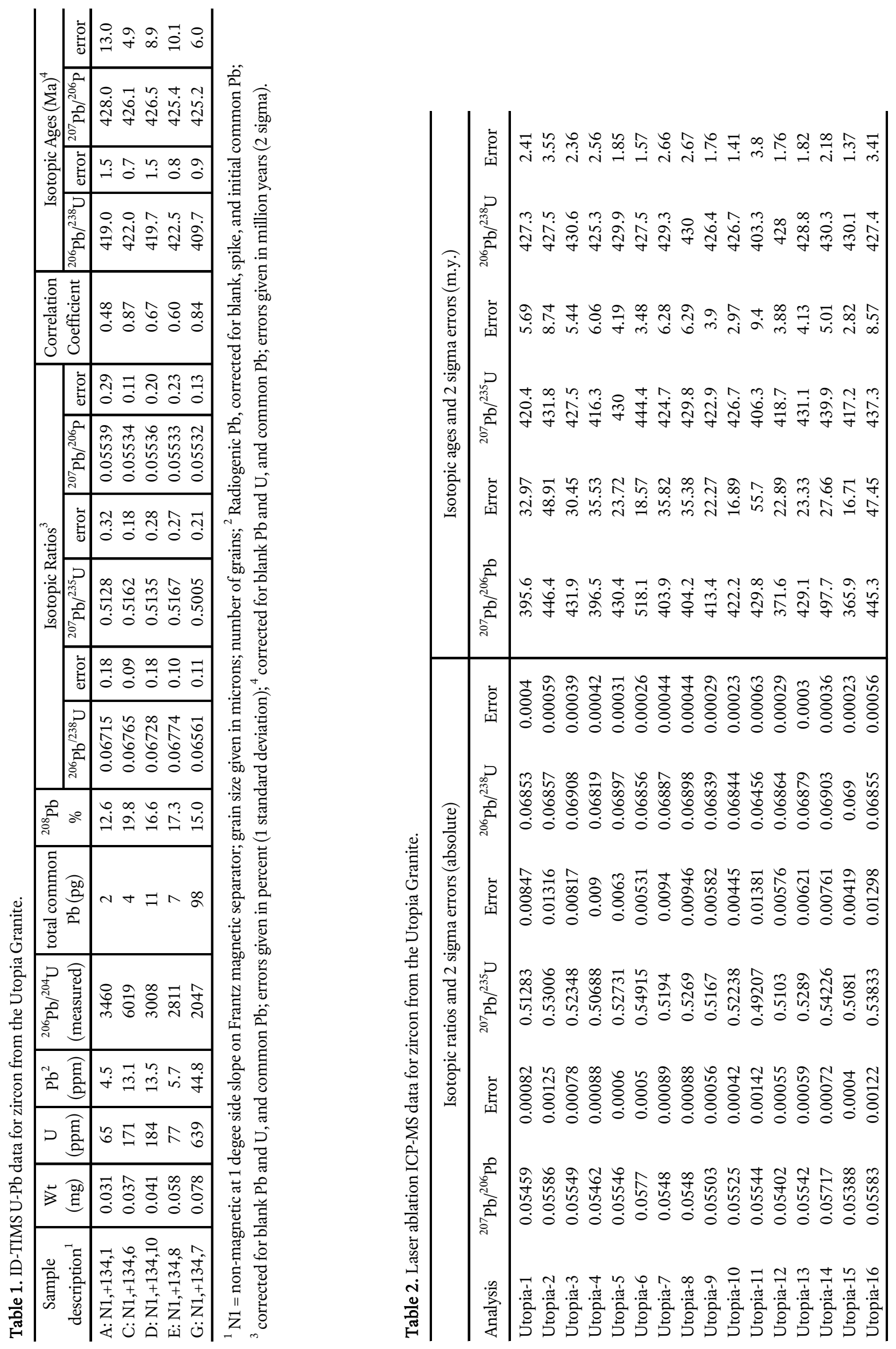
(Fig. 2). A fifth analysis (G) is discordant, reflecting a significant amount of post-crystallization Pb-loss that likely relates to the substantially higher $\mathrm{U}$ content of this fraction (Table 1). Together the five analyses define a discordant array with a calculated upper intercept of $426.3 \pm 5.9 \mathrm{Ma}$ and a lower intercept at $21 \pm 260 \mathrm{Ma}(\mathrm{MSWD}=0.05$; probability of fit $=0.99)$. We interpret the upper intercept to give the crystallization age of the sample, and the lower intercept to reflect mainly relatively young $\mathrm{Pb}$-loss. The data suggest that all five fractions have suffered at least some minor degree of post-crystallization Pb-loss that was not completely removed by the strong air abrasion.

We also applied LA-ICP-MS methods in an attempt to obtain a more precise and robust age for the sample. A total of sixteen zircon grains were analyzed (Table 2), and all but one yielded overlapping concordant analyses (Fig. 3a). A weighted average of the ${ }^{206} \mathrm{~Pb} /{ }^{238} \mathrm{U}$ ages, excluding one younger age, is $428.3 \pm 1.0 \mathrm{Ma}$ (Fig. $3 \mathrm{~b}$; MSWD $=0.66$, probability of fit $=$ 0.81 . We interpret this age as the best estimate for the crystallization age of the Utopia Granite. The younger ${ }^{206} \mathrm{~Pb} /{ }^{238} \mathrm{U}$ age for the single analysis is interpreted to reflect subtle alteration of the analyzed zircon that resulted in minor Pb-loss.

\section{IMPLICATIONS OF THE RESULTS}

Silurian-Devonian gabbroic to granitic plutons of the Saint George Plutonic Suite are contiguous with the coastal Maine magmatic province of Hogan and Sinha (1989), the northeastern part of which in adjacent Maine is the Moosehorn Plutonic Suite of McLaughlin et al. (2003) (Fig. 1). The Baring Granite component of the Moosehorn Plutonic Suite yielded a Late Silurian U-Pb (zircon) age of $421.1 \pm 0.8 \mathrm{Ma}$, and based on field relations and petrology, McLaughlin et al. (2003) concluded

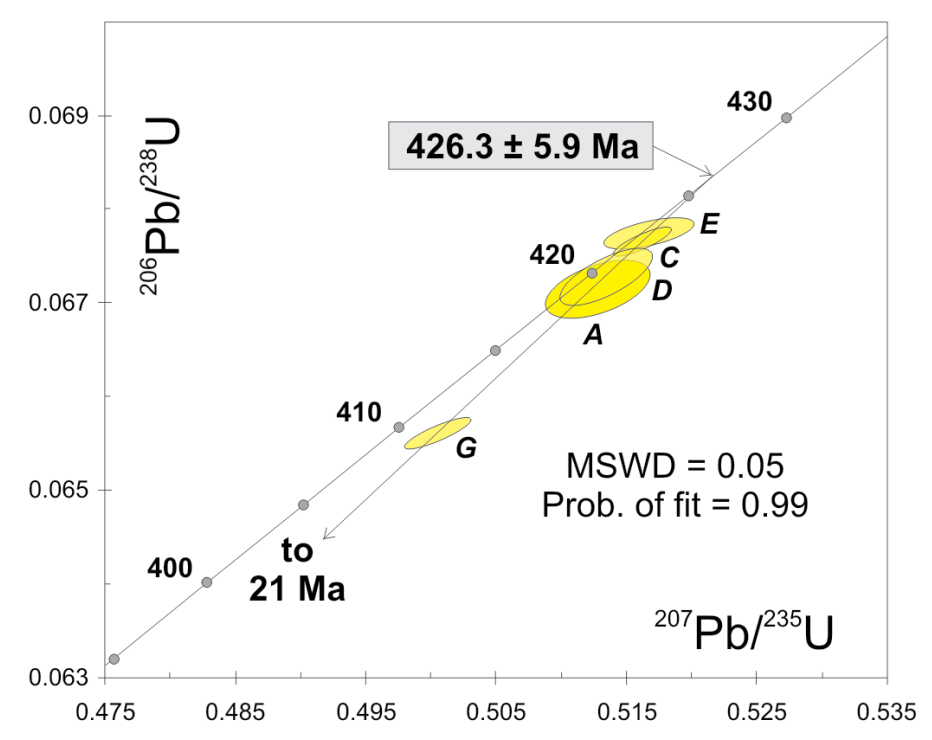

Fig. 2. Concordia plot for ID-TIMS analyses of zircons from Utopia Granite. Error ellipses are shown at a 2 sigma level. that the Baring Granite is approximately contemporaneous with gabbroic and dioritic components of the suite. Based on petrological comparisons, they also suggested that the gabbroic and dioritic components of the Moosehorn Plutonic Suite are correlative with the gabbroic and dioritic components of the Bocabec Gabbro in the Saint George Plutonic Suite and that the granitic component of the Bocabec Gabbro is correlative with the Baring Granite.

The Utopia Granite has been interpreted to have intruded the Bocabec Gabbro, but locally to be veined by granodiorite of the Bocabec Gabbro, suggesting similarity in age (McLeod 1990). The granodiorite was interpreted by McLeod (1990) as a zone of co-mingling between the two plutons, and hence he referred to the Bocabec and Utopia plutons collectively as the Digdeguash Lake Intrusive Suite. However, the age of 428.3 $\pm 1.0 \mathrm{Ma}$ reported here for the Utopia Granite causes prob-
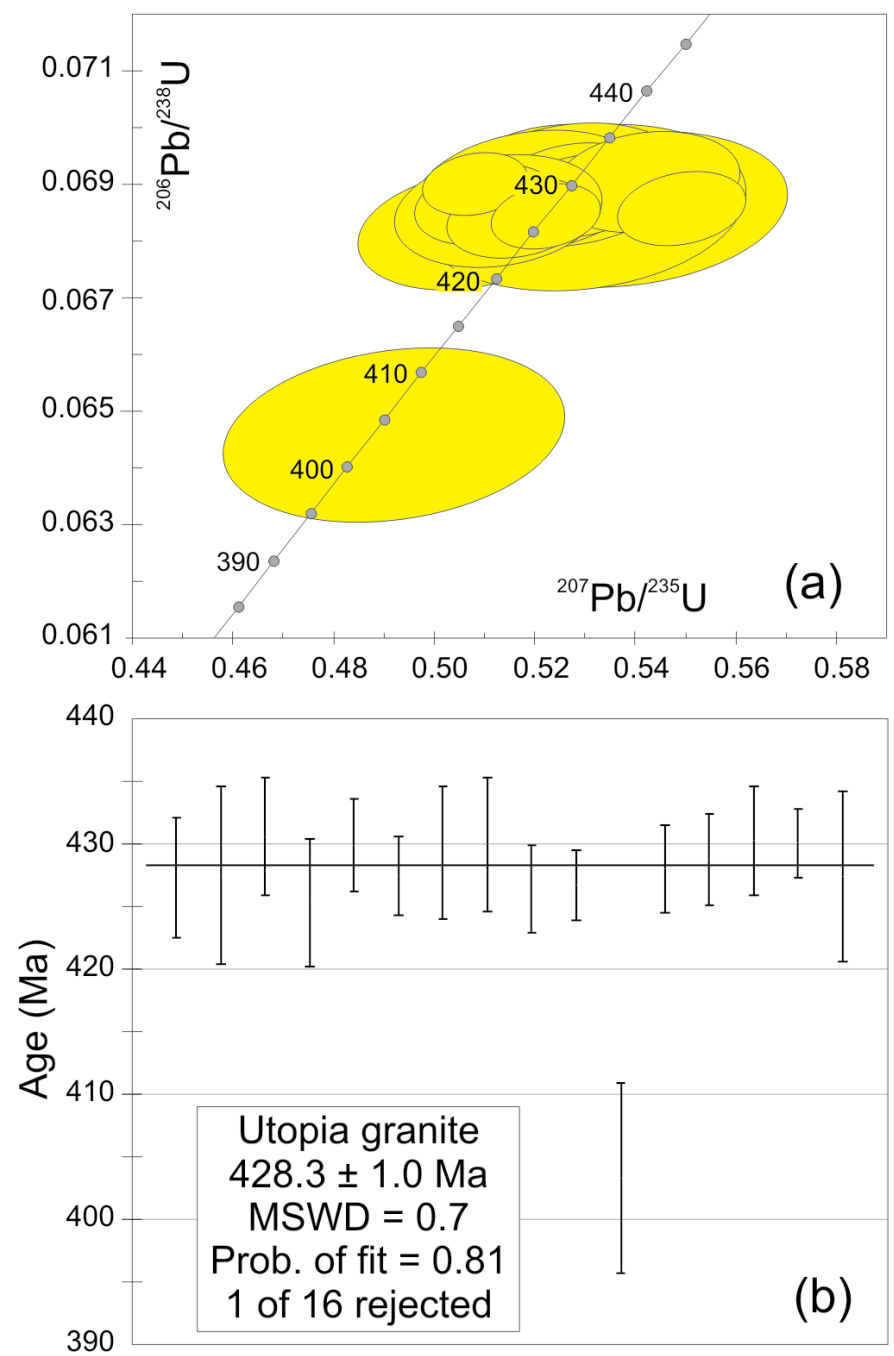

Fig.3. (a) Concordia plot for laser ablation ICP-MS analyses of zircons from the Utopia Granite showing error ellipses at the 2 sigma level. (b) Plot of ${ }^{206} \mathrm{~Pb} /{ }^{238} \mathrm{U}$ ages for sixteen zircon grains from the Utopia Granite with error bars shown at the 2 sigma level. 
lems with these interpretations because it is older than the age of $421.1 \pm 0.8$ Ma reported by McLaughlin et al. (2003) for the Baring Granite. The close petrochemical similarity of the gabbroic and dioritic components of the Bocabec Gabbro and Moosehorn Plutonic Suite suggests that all of these plutons were co-magmatic (McLaughlin et al. 2003). However, the granitic component of the Bocabec Gabbro is generally more similar to the Baring Granite than to the Utopia Granite, which is chemically more evolved (McLaughlin et al. 2003). Rather than the Utopia Granite being a younger, more evolved unit, however, our new age data indicate that it is older than the Baring Granite and hence not directly related. If so, then the co-magmatic relationship between the Utopia Granite and the Bocabec Gabbro also becomes questionable - which pluton is mingled with Bocabec Gabbro, the $421 \mathrm{Ma}$ Baring Granite or the 428 Ma Utopia Granite? Our data do not provide a definitive answer to that question, which would require more petrological studies and/or geochronology, but the ${ }^{40} \mathrm{Ar} /{ }^{39} \mathrm{Ar}$ cooling age of $421 \pm 4 \mathrm{Ma}$ for phlogopite in a gabbroic unit in the Moosehorn Plutonic Suite suggests that it is more likely the Baring Granite.

The age of $428 \mathrm{Ma}$ for the Utopia Granite also brings into question the relationships among the Parks Brook, Jake Lee Mountain, and Welsford alkali granites. McLeod (1990) reported that the Utopia Granite intruded the Parks Brook and Jake Lee Mountain alkali granites, although he did not provide detailed descriptions of the field relationships. Currie (2003) considered these plutons to be correlative with the Welsford Granite. However, the Welsford Granite has a U-Pb zircon age $422 \pm 1 \mathrm{Ma}$ (Bevier 1990), and hence if the intrusive relationship reported by McLeod (1990) is correct, then the U-Pb ages are not consistent with the inferred correlation based on petrological similarities. Fyffe (1998) noted that the Jake Lee Mountain pluton has a core of medium-to coarse-grained, equigranlar riebeckite-bearing granite enveloped by a fine-gained rim of rapakivi granite porphyry. Limited exposure in the area does not preclude the presence of that fine-grained rim of the Jake Lee Mountain pluton everywhere against the Utopia Granite (L.R. Fyffe, written communication 2010), consistent with the latter being older as indicated by the U-Pb age reported here. Alternatively, the Jake Lee Mountain and Parks Brook granites might not be correlative with the Welsford Granite.

The age reported here for the Utopia Granite is older than the ages of other plutons of the coastal Maine magmatic province, which are generally similar to the ages of the Baring and Welsford granites. They include the South Penobscot Pluton (419 $\pm 2 \mathrm{Ma}$, U-Pb, zircon; Stewart et al. 2001), Spruce Head Pluton (421 $\pm 1 \mathrm{Ma}, \mathrm{U}-\mathrm{Pb}$, zircon; Tucker et al. 2001), Cadillac Mountain intrusive complex (424 \pm 2 and $419 \pm 2 \mathrm{Ma}, \mathrm{U}-\mathrm{Pb}$, zircon; Seaman et al. 1995), and Sedgwick Pluton (419.5 \pm 1 $\mathrm{Ma}, \mathrm{U}-\mathrm{Pb}$, zircon; Stewart et al. 2001). Widespread and voluminous Late Silurian volcanic and plutonic activity throughout the coastal Maine magmatic province and adjacent New Brunswick shows that igneous activity was a major characteristic of this area, but the specific tectonic setting in which it occurred is uncertain. The span of ages from the Saint George
Plutonic Suite from $428 \mathrm{Ma}$ to $366 \mathrm{Ma}$ (this study and Bevier 1990) indicates that these plutons are not co-magmatic and were not related to a single orogenic event. Hence the more generic term Saint George batholith seems more appropriate than Saint George Plutonic Suite, as also suggested by McLeod (1990).

\section{ACKNOWLEDGEMENTS}

Fieldwork by Sandra Barr in southern New Brunswick has been funded in part by Natural Sciences and Engineering Research Council of Canada Discovery grants, and by the New Brunswick Department of Natural Resources through grants in aid of research. We thank the staff of the Pacific Centre for Isotopic and Geochemical Research, especially Richard Friedman, for assistance in generating the analytical results presented here. Journal reviewers Les Fyffe and Malcolm McLeod are thanked for their helpful comments which led to clarifications and improvements in the manuscript.

\section{REFERENCES}

Bevier, M.L. 1990. Preliminary U-Pb geochronologic results for igneous and metamorphic rocks, New Brunswick. In Fourteenth Annual Review of Activities, Project Résumés. Edited by S.A. Abbott. New Brunswick Department of Natural Resources and Energy, Minerals and Energy Division, Information Circular 89-2, pp. 190-194.

Currie, K.L. 2003. Geology of the Saint John - Saint George area, southern New Brunswick (NTS 21 G/1, 2E, 7E, 8, H/4W, 5W). Geological Survey of Canada, Open File 1764, $212 \mathrm{p}$ and geological map, scale 1:100 000.

Fyffe, L.R. 1971. Petrogenesis of the adamellite- diorite transition, southwetern New Brunswick. Unpublished M.Sc thesis, University of New Brunswick, Fredericton, New Brunswick, Canada $131 \mathrm{p}$.

Fyffe, L.R. 1998. Bedrock Geology of the Jake Lee Mountain area (NTS 21G/02g), Charlotte County, New Brunswick. New Brunswick Departmernt of Natural Resources and Energy, Minerals and Energy Division, Plate 98-70, scale 1:20 000.

Fyffe, L.R., Pajari, G.E., and Cherry, M.E. 1981.The Acadian plutonic rocks of New Brunswick. Maritime Sediments and Atlantic Geology, 17, pp. 23-36.

Fyffe, L.R., Barr, S.M., Johnson, S.C., McLeod, M.J., McNicoll, V.J., Valverde-Vaquero, P., van Staal, C.R., and White, C.E. 2009. Detrital zircon ages from Neoproterozoic and Early Paleozoic conglomerate and sandstone units of New Brunswick and coastal Maine: Paleogeographic implications for Ganderia and the continental margin of Western Gondwana. Atlantic Geology, 45, pp. 110-144. doi:10.4138/atlgeol.2009.006

Griffin, W.L., Powell, W.J., Pearson, N.J., and O'Reilly, S.Y. 2008. Glitter: Data reduction software for laser ablation 
ICP-MS. In Laser Ablation ICP-MS in the Earth Sciences: Current Practices and Outstanding Issues. Edited by P.J. Sylvester. Mineralogical Association of Canada Short Course Series, Short Course 40, Vancouver, British Columbia, pp. 308-311.

Hibbard, J.P., van Staal, C.R., Rankin, D.W., and Williams, H. 2006. Lithotectonic map of the Appalachian Orogen (North), Canada-United States of America; Geological Survey of Canada, Map 02042A, scale 1:1500 000.

Hogan, J.P., and Sinha, A.K. 1989. Compositional variation of plutonism in the Coastal Maine Magmatic Province: mode of origin and tectonic setting. In Studies in Maine Geology. Edited by R.D. Tucker and R.G. Marvinney, 4, pp. 1-33.

King, M.S., and Barr, S.M. 2004. Magnetic and gravity models across terrane boundaries in southern New Brunswick, Canada. Canadian Journal of Earth Sciences, 41, pp. 1027-1047. doi:10.1139/e04-046

Ludwig, K. 2003. Isoplot/Ex, version 3: A geochronological toolkit for Microsoft Excel: Berkeley Geochronological Centre Special Publication 4, $71 \mathrm{p}$.

McLaughlin, K.J. 2003. The Moosehorn Plutonic Suite of southwestern New Brunswick and southeastern Maine: Petrology, geochemistry, and tectonic setting. Unpublished M.Sc. thesis, Acadia University, Wolfville, Nova Scotia, Canada, 307p.

McLaughlin, K.J., Barr, S.M., Hill, M., Thompson, M., Ramezani, J., and Reynolds, P.H. 2003. The Moosehorn Plutonic Suite, southeastern Maine and southwestern New Brunswick: Age, petrochemistry, and tectonic setting. Atlantic Geology, 39, pp. 123-146.

McLeod, M.J. 1990. Geology, Geochemistry, and Related Mineral Deposits of the Saint George Batholith; Charlotte, Queens, and Kings Counties, New Brunswick. New Brunswick Department of Natural Resources and Energy, Mineral Resources, Mineral Resource Report 5, 169 p.

Miller, B.V. and Fyffe, L.R. 2002. Geochronology of the Letete and Waweig formations, Mascarene Group, southwestern New Brunswick, Atlantic Geology, 38, pp.29-36.

Mortensen, J.K., Ghosh, D., and Ferri, F. 1995. U-Pb age constraints of intrusive rocks associated with Copper-Gold porphyry deposits in the Canadian Cordillera. In Porphyry deposits of the northwestern Cordillera of North America. Edited by T.G. Schroeter. Canadian Institute of Mining and Metallurgy, Special Volume 46, pp. 142-158.

New Brunswick Department of Natural Resources. 2010. Bedrock lexicon of New Brunswick Minerals and Energy
Division. URL <http://www1.gnb.ca/0078/GeoscienceDatabase/Lexicon/GeoSearch-e.asp >, February 2010.

Ruitenberg, A.A., and Fyffe, L.R. 1982. Mineral deposits associated with granitoid intrusions and related subvolcanic rocks in New Brunswick and their relationship to Appalachian tectonic evolution. Canadian Institute of Mining and Metallurgy Bulletin, 75, pp. 83-97.

Seaman, S.J., Wobus, R.A., Wiebe, R.A., Lubick, N., and Bowring, S.A. 1995. Volcanic expression of bimodal magmatism: The Cranberry Island - Cadillac Mountain Complex, coastal Maine. Journal of Geology, 100, pp. 395-409. doi:10.1086/629594

Sláma, J., Košler, J., Condon, D.J., Crowley, J.L., Gerdes, A., Hanchar, J.M., Horstwood, M.S.A., Morris, G.A., Nasdala, L., Norberg, N., Schaltegger, U., Xchoene, B., Tubrett, M.N., and Whitehouse, M.J., 2007, Plešovice zircon - A new natural reference material for $\mathrm{U}-\mathrm{Pb}$ and $\mathrm{Hf}$ isotopic microanalysis. Chemical Geology, 249, pp. 1-35. doi:10.1016/j. chemgeo.2007.11.005

Stewart, D.B., Tucker, R.D., Ayuso, R.A., and Lux, D.R., 2001. Minimum age of the Neoproterozoic Seven Hundred Acre Island Formation and the tectonic setting of the Islesboro Formation, Islesboro Block, Maine. Atlantic Geology, 37, 41-59.

Tafti, R., Mortensen, J.K., Lang, J.R., Rebagliati, M., and Oliver, J.L. 2009. Jurassic U-Pb and Re-Os ages for newly discovered Xietongmen $\mathrm{Cu}$-Au porphyry district, Tibet: Implications for metallogenic epochs in the southern Gangdese Belt. Economic Geology, 104, pp. 127-136. doi:10.2113/ gsecongeo.104.1.127

Tucker, R.D., Osberg, P.H., and Berry, H.N., 2001. The geology of a part of Acadia and the nature of the Acadian orogeny across central and eastern Maine. American Journal of Science, 301, pp. 205-260. doi:10.2475/ajs.301.3.205

Van Achterbergh, E., Ryan, C.G., Jackson, S.E., and Griffin, W.L. 2001. Data reduction software for LA-ICP-MS: appendix. In Laser Ablation - ICP-Mass Spectrometry in the Earth Sciences: Principles and Applications. Edited by P.J. Sylvester. Mineralogical Association of Canada Short Course Series, Ottawa, Ontario, Canada, 29, pp. 239-243.

Van Wagoner, N.A., and Dadd, K.A. 2003. A Silurian age for the Passamaquoddy Bay volcanic sequence in southwestern New Brunswick: implications for regional correlations. Geological Society of America, Abstracts with Programs, 35, No. 3, p. 79. 